\title{
The function of plant pathogenic fungi in natural communities
}

\author{
J.C. Zadoks
}

\section{Detailed contents}

1. Introduction $\ldots \ldots \ldots \ldots \ldots \ldots \ldots \ldots \ldots \ldots \ldots, 201$

2. Ecology of plant inhabiting microorganisms . . . . 202

3. Pathogens in plant communities . . . . . . . . 202

3.1 Population control ................. 203

3.2 Patchiness and microsuccession ........ 204

\section{Introduction}

There seems to be some discrepancy in opinion between vegetation scientists (e.g. Harper, 1977), talking about the effects of plant disease on vegetation, and plant pathologists (e.g. Burdon \& Shattock, 1980; Dinoor \& Eshed, 1984; Thresh, 1981), talking about the effects of vegetation on diseases. The very notion of disease seems to differ between the two disciplines. One vegetation scientist, his identity does not matter here, summarized his view plainly: 'A plant becomes diseased when it is weakened by other causes than pathogens'. This does indeed happen (e.g. Bachi \& Peterson, 1985). For example, the fungus Sphaeropsis sapinea (Fr.) Dyko \& Sutton has become a common disease in Dutch pine plantations since 1982 , especially when trees are weakened (Boerema et al., 1985). Nevertheless, professional plant pathologists have a rather more complex view to offer.

Disease is a condition of an organism, in which the organism does not function normally. The definition implies, that the borderline between diseased and healthy is indistinct and subjective. This paper will be limited to diseases caused by
3.3 Acceleration of succession ................ 204

3.4 Evolutionary segregation .............. 205

4. Concluding remarks $\ldots \ldots \ldots \ldots \ldots \ldots \ldots \ldots \ldots, 206$

Acknowledgements .................. 206

References..................... 206 fungal pathogens. The plants affected by a pathogen are called host plants. Fungal diseases of wild plants are well documented (e.g. Brandenburger, 1985).

Any visible deviation of a host plant is called an injury. Injury may not necessarily cause damage, which is a deviation from the normal production of the plant. Damage in turn may not necessarily have an economic impact, called loss (Zadoks, 1985). For natural vegetation, the notion of loss, but not that of damage, may be ignored. In crop plants, damage can be recognized as a reduction in yield and/or quality of the desired product. It is more difficult to define damage in natural vegetation, but two types of damage, both referring to reproduction, are relevant. Primary damage is a decrease of reproductive capacity in the year of injury, while secondary damage is a decrease of reproductive capacity in the following years ( $\mathrm{Za}$ doks \& Schein, 1979).

One more concept from phytopathology must be introduced here, the concept pathosystem (Robinson, 1976). A population of a pathogenic fungus species interacts with a population of a host plant species in such a way that they exert mutual selection pressures on each other. As a re- 
sult, the two species may develop a subtle genetic interplay in time and space, which is influenced by the environment. The rules of the game are such that both species survive under a given set of ecological conditions, but that the equilibrium between the two species can be upset if the conditions are changed. Either species may be eliminated, but usually the pathogen wins, at least temporarily. Agriculture is troubled by pathogens because man has changed the ecological conditions prevailing in nature and so has disturbed the previously existant equilibrium (a.o. Zadoks \& Schein, 1979).

In biblical times, pests and diseases of crop plants were considered to be punishments of God. This notion continued well into the twentieth century. One plant pathologist called pathogens 'organisms out of place' (Yarwood, 1967). Plant pathogens were associated with evil. They were to be 'banished' (Stakman \& Harrar, 1957, page 541). Some plant pathologists took a different stand, stating that pathogens were part of nature. Consequently, plant pathogens should be managed where necessary, not eradicated ( $\mathrm{Za}$ doks \& Schein, 1979). Since cultivated plants have evolved from wild plants, their pathogens have evolved from natural pathogens. New pathogens, that is pathogens appearing de novo, are extremely rare (Zadoks, 1967).

\section{Ecology of plant inhabiting microorganisms}

Many microorganisms inhabit plants, but relatively few are pathogens. In this review, all epiphytic microorganisms are ignored, even though some may occasionally do damage. The plant-invading microorganisms, which as a rule are beneficial, such as nitrogen fixing bacteria and mycorrhizal fungi, are briefly considered. The fungi, that invade weakened and dead plants and primarily function as decomposers, are not discussed. The review focuses on those microorganisms that are real consumers.

Although the borderlines between ecologically different groups of microorganisms, including various types of pathogens, are not clear-cut, it is often important to distinguish between these groups. There are differences indeed between root-invading pathogens and shoot-invading pathogens. It is relevant to consider whether the pathogenic fungus first kills the host cells and then consumes them, the perthotrophic fungus, or first consumes them and in doing so kills the host cells, the biotrophic fungus. The biotrophs can only survive on living hosts and florish best when the host is growing in optimal condition. The perthotrophs, which often have a saprobic phase, may profit when the host is in a relatively poor condition.

Phytopathology cannot offer the vegetation scientists one simple and straightforward view on plant disease. Fortunately, phytopathologists have recently become more and more interested in the function of pathogens in natural vegetation, for two reasons. One is the feeling that some of the mechanisms to establish equilibrium between host and pathogen, which operate in nature, have been lost in agriculture (Van Leur, 1981). The other is the need to replace chemical control of weeds by biological control using pathogens when and where that is feasible (e.g. Scheepens \& Van Zon, 1982).

\section{Pathogens in plant communities}

Pathogens can affect vegetation in different ways. Some pathogens are specialized on seedlings. They are typical opportunists, following the rstrategy, attacking rapidly when host and circumstances are favourable. They require moist spring conditions at soil level, under a dense canopy. Their role in natural vegetation is not yet well established, but there is evidence that selection for resistance in the host rarely occurs (De Nooij \& Merkx, 1984). Probably, the regulatory function of these opportunists is not too important to plant communities as most of the seedlings would have died anyhow. The situation changes when many plants, even genetically different plants, of one species are placed together for agricultural purposes. For example, dense experimental stands of Aster tripolium L., grown as a delicacy for salad 
making, were rapidly eliminated by damping-off fungi (Knip, 1984).

Intraspecific effects of pathogens on population density and genetic diversity should be separated from interspecific effects of pathogens on species composition of plant communities. The statement 'Diversity is good' used to be a dogma in ecology. The plant pathologist can only make an inverse statement: 'Lack of diversity is a risk' (Zadoks \& Schein, 1979). This lack of diversity is likely to occur when the coevolution of host and pathogen has been interrupted by temporal, spatial, or genetic isolation (Buddenhagen, 1977). For example, the pine forests of the Rocky Mountains, the birch taiga of the USSR, the Limonium vulgare fields of the Dutch island of Terschelling, the Calluna vulgaris heaths of north-west Europe have persisted for long periods. They represent healthy populations of a single dominant species, in spite of the presence of diseased individuals. In an agricultural context, the distinction between interspecific and intraspecific diversity is relevant too. In agriculture, interspecific diversity is often useful, and sometimes dangerous. Intraspecific diversity is usually beneficial, at least with respect to diseases affecting the shoot (Wolfe, 1985; Zadoks \& Schein, 1979).

The role of pathogenic fungi in natural vegetation can be considered at two levels, the population and the vegetation. Each level can be considered at two time scales, one with a time horizon of a few years only, and the other with a horizon between a decade and thousands of years (Table 1).

Table 1. Possible effects of plant pathogenic fungi in natural vegetations according to complexity level and time horizion.

\begin{tabular}{lll}
\hline $\begin{array}{l}\text { Time } \\
\text { horizon }\end{array}$ & \multicolumn{1}{l}{ Complexity level } \\
\cline { 2 - 3 } Short & Population & Vegetation \\
\cline { 2 - 3 } & Population control & $\begin{array}{l}\text { Patchiness, } \\
\text { microsuccession }\end{array}$ \\
Long & $\begin{array}{l}\text { Evolutionary } \\
\text { segregation }\end{array}$ & $\begin{array}{l}\text { Acceleration of } \\
\text { succession }\end{array}$ \\
\hline
\end{tabular}

\subsection{Population control}

It is still uncertain whether pathogens are able to control population density of wild plant species under near-equilibrium conditions. The issue is a central question in the agricultural domain, where biological control of weeds by means of parasitic fungi is studied. Pathogens rarely kill wild plants immediately (e.g. Kranz, 1968). One reason may be the lack of inoculum hitting the target plant (Vanderplank, 1982). The other reason is the presence of various defense mechanisms in the infected plant, at least in the older plant. Seedlings are relatively vulnerable. Damping-off fungi have already been mentioned. These are fungi from different taxonomic groups which cause a rotting of seedlings at soil level. For example, Ernst (1983) stated that 20 per cent of the seedlings of Anemone nemorosa were killed by the fungus Stachybotrys chartarum (Ehrenb. ex Link) Hughes 1 before emergence.

The foregoing referred to elimination of individuals within the growing season. Greater damage can occur over successive seasons, when reproduction or reproductive capacity is diminished. Ernst (1983) provides examples of damage to the perennial $A$. nemorosa by different pathogens. The ascomycete Sclerotinia tuberosa (Fries) Fuckel produces a sclerotium, a firm mass of hyphae, that contains some 30 per cent of the host's rhizome biomass. Flower formation is suppressed and within a few years the host plant dies. The rust fungus Tranzschelia anemones (Pers.) Nannf. inhabits the leaf lamina. The infected plants fail to fruit and the annual weight increase of the rhizome is reduced. The rust fungus Ochropsora ariae (Fuch.) Ramsb. halves fruiting and severely reduces the annual weight increase of the rhizome. All three pathogens reduce host multiplication and endanger host survival.

Jennersten et al. (1983) demonstrate a regulatory effect of the smut fungus Ustilago violacea (Pers.) Roussel on the perennial Viscaria vulgaris (Caryophyllaceae). The fungus effectively sterilizes the plant. The host plants grow in isolated patches, and the larger the patches and the shorter the distances between them, the higher 
the proportion of sterilized plants. It seems as if the fungus slows down the population growth of a patch, once the patch reaches a certain size.

Notwithstanding these selected examples, the effect of pathogenic fungi on population density or size is often limited. Downy mildew (Peronospora farinosa (Fries, 1832) Fr.) can seriously attack the weed Chenopodium album causing premature death of the infected leaves, emergency ripening of the host plant, and reduced seed set. However, the next generation of $C$. album is usually as dense as the foregoing (Frinking and Linders, 1986).

\subsection{Patchiness and microsuccession}

The rust fungus Gymnosporangium juniperinum (L.) Fr. is heteroecious. The asexual phase of the rust multiplies on Sorbus aucuparia, whereas the sexual phase inhabits Juniperus communis. The two hosts, which can grow side by side, are linked together with and by the fungus in a tripartite pathosystem. Sorbus can grow taller than Juniperus and shade it to the degree that Juniperus is killed. However, if the two species come too near to each other the rust may interfere. The rust disperses annually from Juniperus as a source to the nearby Sorbus as a target, and vice versa. Sorbus may be attacked to the extent that leaves, infected by the rust, are dropped prematurely (J.J. Barkman, personal communication). The juniper is not much damaged by the rust. Without rust the Sorbus may kill the Juniperus by shading. With rust the Juniperus may be instrumental in the death of the Sorbus, since repeated premature defoliation weakens trees and renders them susceptible to adverse environmental effects, such as drought and frost, and to fungi attacking weakened plants (e.g. Ostry \& McNabb, 1985; Zadoks \& Schein, 1979). So, the heteroecious rust can influence the distribution of its two hosts.

Natural vegetation is often patchy. For example, a poor meadow may have patches of Trifolium pratense, Holcus lanatus, and other species. The patches are not necessarily stable. W.H. van Dobben (personal communication) suggested a possible role of pathogens. Red clover is suscepti- ble to various species of nematodes and fungi and highly susceptible to several virus diseases. Nematode-induced death comes slowly, but virus kills rapidly. The decline of the clover would allow other species to attain dominance. Similarly, the centre of patches of Limonium vulgare is sometimes overgrown by Festuca rubra. A pathogen may be involved but the evidence is not conclusive. The sequence may prelude the transition from Limonietum to Festucetum (J.G.A. van Leur, unpublished).

Plant pathogens may play a part in these processes of microsuccession, where species succeed each other without changing the aspect of the vegetation as a whole. One can only hypothesize because phytopathological research in microsuccession has seldom if ever been published.

\subsection{Acceleration of succession}

The role of plant pathogens in succession is sometimes very apparent. For example, the willows Salix pulchra and $S$. alaxensis are pioneer species forming nearly pure stands on gravel banks of the river Yukon in Alaska, once the ice has receeded. The willow rust Melampsora bigelowii Thuem appears soon and kills manu seedlings. On higher grounds, willows persist as pure stands. Some fifty years after the establishment of willow, birch and spruce appear, and after about 175 years, the climax forest consists of birch and spruce, with a few relict willows. During the succession the amount of rust declines but various canker and heart rot fungi become abundant and kill the willows (Baxter \& Wadsworth, 1939). The Alaskan season is short, and the process is so slow that the population dynamics of willow and rust can be seen, as if in slow motion, over a period of nearly two centuries. The pathogen apparently accelerated the decline in dominance of willow permitting other species to increase, so accelerating the succession. Note that the foregoing is an interpretative description only; there has been no rustfree control experiment.

The possible acceleration of succession by pathogens was studied in a vegetation of Limonium vulgare on the Dutch island of Terschelling. The 
rust Uromyces limonii (D.C.) Lev. may kill an incidental plant but it does not cause an acceleration of succession. Powdery mildew (Erysiphe communis Wallr.) Link.) is locally so severe, that succession seems to be accelerated indeed. As Limonium is a slow growing perennial, the process goes in slow motion again.

Pathogenic catastrophies are rare in nature. Coevolution of host and pathogen equilibrate the pathosystem. Only when host and pathogen meet again after long separation, does a 'new encounter disease' (Buddenhagen, 1977) occur and an explosive epidemic may start. Several examples of such explosive epidemics are known. In North America the fungus Endothia virginiana P.J. and H.W. Anderson caused an unimportant disease on American chestnuts (Castanea dentata (Marsh.) Borkh.), while in China, the fungus Endothia parasitica (Murr.) P.J. and H.W. Anderson caused an insignificant disease on East Asian chestnut (C. mollissima Bl., $C$. crenata Sieb. et Zucc.). Around 1900, E. parasitica was inadvertently introduced in North America. Since $C$. dentata had no resistance against this fungus the new encounter caused a tragedy. By 1930, the chestnut forests of the Apalachian Mountains, over a million hectares, did no longer exist. Only secondary oak forest survived (Zadoks \& Schein, 1979):

Another devastating epidemic occurred on Zostera marina. Around 1935 some 15000 hectares of evergreen submarine pastures were cleared away in the Dutch Shallows. The epidemic began in Portugal and reached the United Kingdom and Scandinavia within a few years. The pathogen, supposedly Labyrinthula macrocystis Cienk., already occurred on Zostera at the east coast of the USA (Zadoks, 1967). The pathogen may have crossed the Atlantic Ocean aboard ship. (Note that some authors disagree with the disease theory, e.g. Rasmussen, 1973).

Probably both these pathogenic catastrophies were anthropogenic, i.e. the new encounter was man-made. New encounter diseases in crops can have enormous economic consequences. A modest but recent example of a new encounter is an outbreak of downy mildew on an ornamental crop called Texas-bluebell, Lisianthus russellianus (Gentianaceae), originating from the USA and grown in the greenhouse district south of The Hague, in the Netherlands. The causal fungus, Peronospora chlorae de Bary, was traced to Centaurium pulchellum (Gentianaceae), which grows naturally in the dunes separating the greenhouse district from the North Sea (Boerema et al., 1984).

\subsection{Evolutionary segregation}

Longer term evolutionary processes can be reconstructed from shorter term processes (Harlan, 1976). Grasses of the genus Hordeum are parasitized by a rust of the genus Uromyces. The rust is heteroecious; its dikaryotic phase lives on grasses and its haploid phase lives on species of the Liliaceae. Both the haploid and the diploid phases are able to specialize on one or more host species. A highly complex pattern of mutual infections between barley species and liliaceous species has evolved. The complexity is greatest in the gene centre of Hordeum, the Near East, where it has been studied in detail (Anikster \& Wahl, 1979). The environmental effect on speciation has been considered too. Leopoldia eburnea, a bulbous plant of the Negev desert, has received special attention. It flowers only if seasonal rainfall is sufficient, and in very dry seasons the plants do not emerge at all. In the Negev, Leopoldia is never rusted, but in experiments Leopoldia was found to be susceptible to all Uromyces species from Hordeum spp. (Anikster et al., 1980; Anikster \& Wahl, 1984). Consequently, Leopoldia is supposed to be the primordial host of the haploid Uromyces. It seems that $L$. eburnea has been eliminated from Hordeum's gene centre and now occurs only in a peripheral area, where ecological conditions are such that Hordeum can barely survive and the rust not at all. It appears that, in its struggle for life, L. eburnea has lost all its resistance genes arriving at a state in which it is very susceptible to and, at the same time, free from infection. The pathogen in the course of its evolution has apparently forced its host into an ecologically marginal environment, where the pathogen 
itself cannot survive. This process I call 'evolutionary segregation', the converse of coevolution. It is an audaceous thought, for which no direct proof can yet be given, but which may stimulate further study.

\section{Concluding remarks}

From an agricultural point of view, the most interesting aspects of pathogens in natural vegetation are found in the area of pathosystem genetics. These can only be indicated superficially. Extensive studies have been made of wild grass stands in Israel (Browning, 1974). The effect of pathogenic fungi on the genetic composition of plant populations, i.e. on within-species diversity, is manifest, though it can be moderated by environmental conditions.

The effect of pathogenic fungi on species composition of a vegetation, i.e. on between-species diversity, is difficult to prove. Acceleration of succession seems to be the most evident effect, but its frequency is unknown. The causal relation between pathogens and patchiness can be studied experimentally if a period of five to ten years is available. The possibility of pathogen-induced 'evolutionary segregation' is proposed, but the collection of data and the performance of supporting experiments requires decades rather than years.

New encounters have been organized to control weeds, rather successfully in Australia, where the imported composite Chondrilla juncea is effectively controlled by the imported rust Puccinia chondrillina Bubak \& Syd., but without much success for the same pathosystem in the Pacific northwest of the USA (Adams \& Line, 1984). The difference is probably in the environmental conditions. For a new encounter a single introduction should be sufficient. Where host and pathogen have coevolved, another approach is needed. The 'inundation technique' can be successful, as with the leaf flecking fungus Colletotrichum gloeosporioides (Penz.) Sacc. used against Aeschynomene virginica, a weed of rice in the USA (Scheepens and Van Zon, 1982). The fun- gus is massively applied as a microbial herbicide (Templeton et. al., 1984) under the trade name Collego.

Studies of the biological control of weeds have led to a deepening of our insight into pathosystems of natural biocoenoses. The present state of knowledge allows us to reach only preliminary conclusions. Pathogenic fungi are an essential part of every biocoenosis, but their impact on vegetation is of incidental importance only. Such a conclusion is not amazing in view of the often mentioned coevolution of host and pathogen. Coevolution has proceeded to the degree that the pathogen produces altruistic genes, genes which limit the diseasing capacity of the pathogen with respect to the number of infectible host individuals. Genes for virulence can be hypostatically hidden, ready for use if the need arises. The pathogen pays a price to survive for ever.

\section{Acknowledgements}

Thanks are due to Professor J.J. Barkman for suggestions and constructive criticism, to Dr. W.G. Beeftink for comments, and to Dr. J. Anikster for information on Leopoldia.

\section{References}

Adams, E.B. \& Line, R.F. (1984). Epidemiology and host morphology in the parasitism of rush skeleton weed by Puccinia chondrillina. Phytopathology 74: 745-748.

Anikster, Y., Moseman, J.G. \& Wahl, I. (1980). Development of basidia and basidiospores in Uromyces species on wild barley and Liliaceae in Israel. Trans. Br. mycol. Soc. 75: 377-382.

Anikster, Y. \& Wahl, I. (1979). Coevolution of the rust fungi on Gramineae and Liliaceae and their hosts. Annu. Rev. Phytopathology 17: 367-403.

Anikster, Y. \& Wahl, I. (1984). Puccinia hordei and Uromyces species on Hordeum and their relationship. Rept. Tottori Mycol. Inst. (Japan) 22: 97-101.

Bachi, P.R. \& Peterson, J.L. (1985) Enhancement of Sphaeropsis sapinea stem invasion of pines by water deficits. Plant Disease 69: 798-799.

Baxter, D.V. \& Wadsworth, F.H. (1939). Forest and fungus succession in the lower Yukon Valley. Bull. Univ. Michigan School of Forestry and Conservation, Ann Arbor, No. 9, 52 pp. 
Boerema, G.H., Loerakker, W.M. \& Kesteren, H.A. van (1984). Valse meeldauw bij Lisianthus russellianus. Versl. Meded. Plziektenk. Dienst 162 (Jaarboek 1983): 16-18.

Boerema, G.H., Kesteren, H.A. van \& Loerakker, W.M. (1985). Vermeldenswaardige schimmelaantastingen in de periode 1980-1984. Gewasbescherming 16: 103-119.

Brandenburger, W. (1985). Parasitische Pilze an Gefaesspflanzen in Europa. Stuttgart: Fischer. 1248 pp.

Browning, J.A. (1974). Relevance of knowledge of about natural ecosystems to development of pest management programs for agro-ecosystems. Proc. Amer. Phytopathol. Soc. 1: 191-199.

Buddenhagen, I.W. (1977). Resistance and vulnerability of tropical crops in relation to their evolution and breeding. Ann. New York Acad. Sciences. 287: 309-326.

Burdon, J.J. \& Shattock, R.G. (1980). Disease in plant communities. Applied Biology 5: 145-219.

Dinoor, A. \& Eshed, N. (1984). The role and importance of pathogens in natural plant communities. Annu. Rev. Phytopathology 22: 443-466.

Ernst, W.H.O. (1983). Population biology and mineral nutrition of Anemona nemorosa with emphasis on its parasitic fungi. Flora (DDR) 173: 335-348.

Frinking, H.D. \& Linders, E.G.A. (1986). A comparison of two pathosystems: downy mildew on Spinacia oleracea and on Chenopodium album. Netherlands J. Plant Pathology 92: 97-106.

Harlan, J.R. (1976). Diseases as a factor in plant evolution. Annu. Rev. Phytopathology 14: 31-51.

Harper, J.C. (1977). Population-biology of plants. Academic Press, London. 892 pp.

Jennersten, O., Nilsson, S.G. \& Wastljung, U. (1983). Local plant populations as ecological islands: the infection of Viscaria vulgaris by the fungus Ustilago violacea. Oikos (Acta Oecol. Scand.) 41: 391-395.

Knip, K. (1984). Lamsoor en breeksla uit eigen tuin. NRC. Handelsblad 14 juli 1984.

Kranz, J. (1968). Eine Analyse von annuellen Epidimieen pilzlicher Parasiten. II. Qualitative und quantitative Merkmale von Befallskurven. Phytopathol. Z. 61: 171-190.

Leur, J.G.A. van (1981). Onderzoek naar het evenwicht tus- sen waard en pathogenen in een natuurlijke situatie. Vakblad Biologen 61: 466-471.

Nooij, M.P. de \& Merkx, T. (1984). The influence of parasitic soil micro-organisms on seedling establishment in Plantago lanceolata. Progress Rep. Inst. Ecol. Res. 1983: 53-55.

Ostry, M.E. \& McNabb Jr, H.S. (1985). Susceptibility of Populus species and hybrids to disease in the North Central United States. Plant Disease 69: 755-757.

Rasmussen, E. (1973). Systematics and ecology of the Isefjord marine fauna (Denmark). With a survey of the Eelgrass (Zostera) vegetation and its communities. Ophelia 11: 1-507.

Robinson, R.A. (1976). Pathosystems. Berlin: Springer. 184 pp.

Scheepens, P.C. \& Zon, H.C.J. van (1982). Microbial herbicides. In: Kurstak, E. (Ed.), Microbial and viral pesticides, pp 623-641. Marcel Dekker, New York. 720 pp.

Stakman, E.C. \& Harrar, J.G. (1957). Principles of plant pathology. Ronald Press, Cy. New York. 581 pp.

Templeton, G.E., TeBeest, D.O. \& Smith jr., R.J. (1984). Biological weed control in rice with a strain of Colletotrichum gloeosporioides (Penz.) Sacc. used as a mycoherbicide. Crop Protection 3: 411-424.

Thresh, J.M. (Ed.) 1981). Pests, pathogens and vegetation. The role of weeds and wild plants in the ecology of crop pests and diseases. Pitman, London. 517 pp.

Vanderplank, J.E. (1982). Host-pathogen interactions in plant disease. Academic Press, New York. 207 pp.

Wolfe, M.S. (1985). The current status and prospects of multiline cultivars and variety mixtures for disease resistance. Annu. Rev. Phytopathology 23: 251-273.

Yarwood, C.E. (1967). Pathogens as organisms out of place. Phytopathol. Z. 58: 305-314.

Zadoks, J.C. (1967). International dispersal of fungi. Neth. J. Pl. Path. 73: Suppl. 1:61-80.

Zadoks, J.C. (1985). On the conceptual basis of crop loss assessment: the threshold theory. Annu. Rev. Phytopathology. 23: $455-473$.

Zadoks, J.C. \& Schein, R.D. (1979). Epidemiology and plant disease management. Oxford University Press, New York. 427 pp. 